\title{
FAKTOR- FAKTOR YANG MEMPENGARUHI KEPUASAN PELANGGAN PADA PT. PLN WILAYAH SUMUT CABANG LUBUK PAKAM RANTING MEDAN DENAI
}

\author{
Oleh: \\ Dra. Elisabeth Simangunsong, M.Si
}

\begin{abstract}
ABSTRAK
Elisabeth, This study aims to identify and analyze the factors that affect customer satisfaction. Benefits of the research is to provide input to the PLN in order to deliver a quality service. The population of this study were all customers of PT. PLN (Persero) Regional Branch of North Sumatra Medan Denai Lubukpakam Branch. A sample of 125 respondents. Data collection techniques by questionnaire and documentation. Data analysis techniques by factor analysis.

Results of research and discussion shows from 25 variables were observed before the rotation are 15 variables that have a correlation coefficient above 0.5 setelahrotasi to 23 variables as the dominant factor influencing customer satisfaction. Of the 23 variables are grouped into eight factors: Factor 1: Understanding customer needs, quick service, hospitality employees, Employee Attitudes, place of service is safe and sympathetic attitude. FACTOR 2: Attention sincere, timeliness of service and employee performance. FACTOR 3: The equipment used and the speed of service, FACTOR 4: Respond to complaints and handling problems, FACTOR 5: Concern officer, Presedur petition and competence of employees, FACTOR 6: Willingness employee help, Conformity implementation and Recency of equipment, FACTOR 7: Information clear and sense of security during the deal and FACTOR 8: Attention Patience officers and employees.

Conclusion There are 23 variables as the dominant factor affecting customer satisfaction, namely: understanding customer needs, fast service, friendliness of employees, employee attitudes, a safe care, attitudes sympathetic, genuine concern, timeliness of service, the appearance of an employee, the equipment used, speed of service, response to complaints, troubleshoot problems, care attendant, Presedur petition and employee competencies, employee willingness to help, Conformity implementation, recency equipment, clear information, Sense of security during the deal, the attention of officers and employees Patience. While the suggestions need to improve the quality of services quickly and accurately through the training and development of employees, disseminating the manual system with computerized equipment online payment of electricity bills to provide convenience for customers and establish mutually beneficial relationship
\end{abstract}

\section{PENDAHULUAN}

Salah satu organisasi yang bergerak dalam bidang jasa/pelayanan kepada publik adalah Perusahaan Listrik Negara (PLN). PLN (Persero) yang bergerak dalam bidang kelistrikan di Indonesia. PLN mempunyai tugas sebagai pengelola transmisi dengan kualitas pelayanan yang mampu memenuhi harapan stakeholder dan memberikan konstribusi dalam peningkatan kesejahteraan masyarakat. Salah satu bentuk pelayanan kepada masyarakat adalah Payment Point Online Bank (PPOB). PPOB adalah suatu loket penerimaan pembayaran tagihan listrik dari pelanggan PLN yang langsung online dengan bank. Tujuannya untuk memberikan kemudahan bagi pelanggan serta persaingan yang sehat di antara penyedia jasa pembayaran rekening listrik. Sistem PPOB ini dilakukan untuk menciptakan tingkat kepuasan pelanggan yang semaksimal mungkin. 
Kepuasan pelanggan mempunyai hubungan yang kuat dengan kualitas pelayanan. Kualitas pelayanan memberikan suatu dorongan kepada pelanggan untuk menjalin hubungan yang kuat dengan perusahaan. Dalam jangka panjang memungkinkan perusahaan untuk memahami dengan seksama harapan pelanggan. Dengan demikian perusahaan dapat meningkatkan kepuasan pelanggan di mana perusahaan memaksimumkan pengalaman pelanggan yang menyenangkan dan meminimumkan pengalaman pelanggan yang kurang menyenangkan (Atmawati dan Wahyuddin, 2007). Kepuasan pelanggan telah menjadi konsep sentral dalam wacana bisnis dan manajemen (Tjiptono dan Chandra, 2005: 192). Pelanggan umumnya mengharapkan produk berupa barang atau jasa yang dikonsumsi dapat diterima dan dinikmatinya dengan pelayanan yang baik atau memuaskan (Assauri, 2003: 28). Kepuasan pelanggan dapat membentuk persepsi dan selanjutnya dapat memposisikan produk perusahaan di mata pelanggannya.

Atmawati dan Wahyuddin (2005) menerangkan bahwa kepuasan pelanggan dipengaruhi oleh persepsi kualitas jasa, kualitas produk, harga dan faktor-faktor yang bersifat situasi sesaat. Salah satu faktor yang menentukan kepuasan pelanggan adalah persepsi pelanggan mengenai kualitas jasa yang berfokus pada lima dimensi kualitas jasa yaitu bukti fisik, keandalan, daya tanggap, jaminan dan empati. Pada dasarnya tujuan dari suatu bisnis adalah untuk menciptakan pelanggan yang puas. Terciptanya kepuasan pelanggan dapat memberikan beberapa manfaat, diantaranya hubungan antara perusahaan dan pelanggannya menjadi harmonis, memberikan dasar yang baik bagi pembelian ulang dan terciptanya loyalitas pelanggan, dan membentuk suatu rekomendasi dari mulut- ke mulut (word of mouth) yang menguntungkan bagi perusahaan (Tjiptono, 1997).

Kepuasan pelanggan merupakan respon pelanggan terhadap kualitas pelayanan yang diberikan. Apabila tingkat kepentingan yang diharapkan sesuai dengan kinerja aktual yang dirasakanya, maka akan tercapai tingkat kepuasan. Demikian juga sebaliknya apabila tingkat kepentingan yang diharapkan tidak sesuai dengan kinerja actual yang dirasakan, maka akan terjadi ketidakpuasan. Kepuasan pelanggan akan dipengaruhi berbagai faktor yaitu, sikap tanggap terhadap gangguan, kemudahan dalam pembayaran tagihan rekening listrik, prosedur pemasangan listrik dan sebagainya.

Beberapa temuan hasil penelitian sebelumnya yaitu : Wahyuddin dan Muryati (2001) dalam penelitiannya menguji faktor-faktor yang mempengaruhi kepuasan pelanggan pada Perusahan Daerah Air Minum (PDAM) Kabupaten Klaten. Hasilnya menunjukkan bahwa terdapat pengaruh signifikan antara variable atribut produk, pelayanan, dan harga terhadap kepuasan pelanggan. Variabel atribut produk dan pelayanan memiliki arah hubungan positif sedangkan harga arah hubungannya negatip.

Susanto (2001) dalam penelitiannya menguji faktor-faktor yang mempengaruhi kepuasan nasabah BPR BKK Karangmalang Kabupaten Sragen. Hasilnya menunjukkan bahwa terdapat pengaruh signifikan antara variabel produk, pelayanan, fasilitas, lokasi, dan keamanan terhadap kepuasan pelanggan/nasabah.

Muhaemin (2005) dalam penelitiannya menguji faktor-faktor yang mempengaruhi kepuasan nasabah PT. Bank BPD Jateng Cabang Surakarta. Hasilnya menunjukkan bahwa terdapat pengaruh signifikan antara variabel keandalan, ketanggapan, dan kepastian terhadap kepuasan nasabah; sedangkan pengaruh variabel ketegasan dan keperwujudan terhadap kepuasan nasabah tidak signifikan. Persoalannya adalah bagaimanakah pengaruh kualitas pelayanan medis, kualitas pelayanan paramedis, dan kualitas pelayanan penunjang medis terhadap kepuasan konsumen/pelanggan di Rumah Sakit Islam Manisrenggo Klaten. Penyelesaian terhadap masalah ini dapat menggunakan sebagai acuan bagi praktisi dan bagi pimpinan Rumah Sakit Islam Manisrenggo Klaten untuk pembenahan kualitas pelayanannya.

PT. PLN Persero Wilayah Sumut Cabang Lubuk Pakam Ranting Medan Denai salah satu Perusahaan Listrik Negara di kabupaten Deli Serdang yang bertujuan untuk 
memenuhi kebutuhan masyarakat. PLN dari sudut pandang pemasaran masih dianggap seller's market dan terdapat unsur monopoli dalam penguasaan pasar. Walaupun pemasarannya mungkin tidak perlu harus segencar pemasaran perusahaan lainnya, namun PLN harus juga memperhatikan aspek pemasaran lebih luas antara lain harus tanggap atas keluhan-keluhan konsumen seperti pencatatan meteran oleh petugas yang tidak akurat, sistem penagihan yang tidak akurat, sistem pembayaran yang antri, pelanggan selalu terancam dengan pemutusan listrik dan sebagainya.

PT. PLN Persero Wilayah Sumut Cabang Lubuk Pakam Ranting Medan Denai sebagai penyelenggara jasa listrik untuk umum dalam melayani pembayaran rekening listrik telah mengantisipasi dengan program komputerisasi pelayanan online kepada pelanggan. Seiring dengan perkembangan ilmu pengetahuan dan teknologi serta system informasi yang mengotomatisasikan jenis-jenis pelayanan yang selama ini dilakukan secara manual. Dengan perubahan pelayanan secara manual menjadi komputerisasi di satu sisi memberikan kemudahan pelayanan tetapi di sisi lain dapat menimbulkan ketidakpuasan bagi pelanggan. Misalnya dalam hal pembayaran tagihan listrik yang disubkontrakkan kepada pihak swasta yang pada akhirnya akan menambah biaya bagi pihak pelanggan. Kepuasan pelanggan ditentukan oleh kualitas produk/jasa yang dikehendaki pelanggan, sehingga jaminan kualitas jadi prioritas utama bagi setiap perusahaan, yang pada saat ini khususnya dijadikan sebagai tolok ukur keunggulan daya saing perusahaan.

Demikian halnya kepuasan pelanggan PT. PLN Persero Wilayah Sumut Cabang Lubuk Pakam Ranting Medan Denai khususnya dalam hal pelayanan pembayaran rekening listrik semua pelanggan menginginkan kemudahan dalam pembayaran, cepat dalam bertransaksi, tepat dalam penghitungan biaya penggunaannya dan dapat diandalkan pelayanannya. Berdasarkan latar belakang masalah di atas, maka yang menjadi masalah yang akan diteliti yaitu : "Faktor - faktor apa penentu yang paling dominan mempengaruhi kepuasan pelanggan pada PT. PLN Persero Wilayah Sumut Cabang Lubuk Pakam Ranting Medan Denai .

\section{Pengertian Pemasaran Jasa}

\section{KAJIAN TEORITIS}

Kegiatan pemasaran tidak terlepas dari fungsi-fungsi organisasi yang lain yang bertujuan menciptakan kepuasan pelanggan. Bauran pemasaran jasa merupakan pengembangan bauran pemasaran. Bauran pemasaran (Marketing Mix) yang hanya mencakup 4P yaitu : Product, Price, Place dan Promotion). Bauran pemasaran tersebut dikembangkan para ahli pemasaran dengan menambahkan tiga unsur yaitu : People, Process dan Custumer Service (Lupiyoadi (2001)

Menurut Lupiyoadi (2001), Marketing Mix jasa terdiri dari tujuh komponen yaitu : Product (jasa seperti apa yang ingin ditawarkan kepada konsumen), Price (bagaimana strategi penentuan harga), Place (bagaimana system penghantaran/penyampaian yang akan diterapkan), Promotion (bagaimana promosi yang harus dilakukan), People (tipe kualitas dan kuantitas orang yang akan terlibat dalam pemberian jasa), Process (bagaimana proses dalam operasi jasa), Customer Service (bagaimana pelayanan yang akan diberikan kepada konsumen).

Menurut Yazid (1999), pemasaran jasa adalah perencanaan yang bergerak dari focus pada transaksi menjadi hubungan jangka panjang dengan pelanggan. Sedangkan menurut Lupiyoadi (2001), pemasaran jasa adalah setiap tindakan yang ditawarkan oleh salah satu pihak ke pihak lain yang secara prinsip intangible dan tidak menyebabkan perpindahan kepemilikan apapun. Sedangkan menurut Umar (2002), pemasaran jasa adalah pemasaran yang bersifat intagibel dan immaterial dan dilakukan pada saat konsumen berhadapan dengan produsen. Dari defenisi diatas dapat disimpulkan bahwa pemasaran jasa suatu 
tindakan yang ditawarkan pihak produsen kepada konsumen dalam arti jasa yang diberikan tidak dapat dilihat, dirasa, didengar atau diraba sebelum dibeli atau dikonsumsi.

\section{Karakteristik Jasa}

Berbagai riset dan literature manajemen dan pemasaran jasa mengungkapkan bahwa jasa memiliki empat karateristik yang membedakan barang dan jasa yang dinamakan paradigma IHIP : Intangibility, Heterogeneity, Inseparability dan Perishability (Lovelock dan Gummesson, dalam Fandy Tjiptono dan Gregorius Chandra, 2005).

1. Intangibility. Jasa bersifat Intangibility artinya jasa tidak dapat dilihat, dirasa, didengar, atau diraba sebelum dibeli dan dikonsumsi. Seorang konsumen jasa tidak dapat menilai hasil dari sebuah jasa sebelum ia mengalami atau mengkonsumsinya sendiri. Apabila pelanggan membeli jasa tertentu maka ia hanya menggunakan, memanfaatkan atau menyewa jasa tersebut, namun tidak memiliki jasa yang dibelinya.

2. Heterogeneity. Jasa bersifat Heterogeneity karena merupakan non- standardized output artinya terbanyak variasi bentuk, kualitas dan jenis, tergantung pada siapa, kapan dan dimana jasa tersebut diproduksi. Contoh :: Dua orang yang dating ke salon yang sama dan meminta model yang sama tidak akan mendapatkan hasil yang seratus persen sama.

3. Inseparability. Jasa bersifat Inseparability artinya jasa dijual terlebih dahulu kemudian baru diproduksi dan dikonsumsi pada waktu dan tempat yang sama. Berbeda dengan produk yang biasanya diproduksi terlebih dahulu baru dapat dikonsumsi.

4. Perishability. Jasa bersifat Perishability artinya jasa merupakan komoditas yang tidak tahan lama, tidak dapat disimpan untuk pemakaian ulang di waktu yang akan datang, dijual kembali atau dikembalikan.

Sedangkan menurut Griffin dalam Lupiyoadi (2001) menyebutkan karakteristik Jasa yaitu:

a. Intangibility (tidak berwujud). Jasa tidak dapat dilihat, dirasa, diraba, didengar, atau dicium sebelum jasa itu dibeli. Nilai penting dari hal ini adalah nilai tidak berwujud yang dialami konsumen dalam bentuk kenikmatan, kepuasan, atau rasa aman.

b. Unstorability. Jasa tidak mengenal persediaan atau penyimpanan dari produk yang telah dihasilkan. Karakteristik ini disebut juga tidak dapat (inseparability) dipisahkan mengingat pada umumnya jasa dihasilkan dan dikonsumsi secara bersama.

c. Customization. Jasa juga sering kali di desain khusus untuk kebutuhan pelanggan, sebagaimana pada jasa asuransi dan kesehatan.

\section{Pengertian Kualitas Pelayanan}

Kualitas pelayanan dapat didefinisikan sebagai seberapa jauh perbedaan antara kenyataan dan harapan para pelanggan atas layanan yang mereka terima. Kualitas pelayanan dapat diketahui dengan cara membandingkan persepsi para pelanggan atas layanan yang benar-benar mereka terima.

Menurut Lewis \& Booms dalam Tjiptono \& Chandra (2005), kualitas pelayanan sebagai ukuran seberapa baik tingkat layanan yang diberikan mampu sesuai dengan harapan pelanggan. Sedangkan menurut Tjiptono (2001), kualitas pelayanan adalah tingkat keunggulan yang diharapkan dan pengendalian atas tingkat keunggulan tersebut untuk memenuhi keinginan pelanggan.

Berdasarkan pendapat diatas, faktor utama yang mempengaruhi kualitas pelayanan yaitu, jasa yang diharapkan dan jasa yang dirasakan / dipersepsikan. Apabila jasa yang dirasakan sesuai dengan jasa yang diharapkan, maka kualitas pelayanan tersebut akan dipersepsikan memuaskan. Jika jasa yang dipersepsikan melebihi jasa yang diharapkan, maka kualitas jasa dipersepsikan sebagai kualitas ideal. Demikian juga sebaliknya apabila jasa yang dipersepsikan lebih jelek dibandingkan dengan jasa yang diharapkan maka 
kualitas jasa dipersepsikan tidak memuaskan. Baik tidaknya kualitas pelayanan tergantung pada kemampuan penyedia jasa dalam memenuhi harapan pelanggannya secara konsisten.

Untuk mempermudah penilaian dan pengukuran kualitas pelayanan dikembangkan suatu alat ukur kualitas layanan yang disebut SERVQUAL (service Quality). SERVQUAL ini merupakan skala multi item yang dapat digunakan untuk mengukur persepsi pelanggan atas kualitas layanan yang meliputi lima dimensi (Zeithami, 1990 hal. 143) yaitu :

1. Tangibles (bukti langsung), yaitu kemampuan suatu perusahaan dalam menunjukkan eksistensinya kepada pihak eksternal. Penampilan dan kemampuan sarana dan prasarana fisik perusahaan dan keadaan lingkungan sekitarnya adalah bukti nyata dari pelayanan yang diberikan perusahaan.

2. Reliability (kehandalan) yaitu kemampuan untuk memberikan pelayanan yang dijanjikan dengan segera, akurat dan memuaskan. Kinerja harus sesuai dengan harapan pelanggan yang berarti ketetapan waktu, pelayanan yang sama untuk semua pelanggan tanpa kesalahan, sikap simpatik dan akurasi yang tinggi.

3. Responsiveness (daya tanggap) yaitu kemampuan maskapai penerbangan untuk membantu dan memberikan pelayanan yang cepat (responsif) dan tepat kepada para pelanggan dengan penyampaian informasi yang jelas. Membiarkan pelanggan menunggu tanpa adanya suatu alasan yang jelas menyebabkan persepsi yang negatif dalam kualitas pelayanan.

4. Assurance (jaminan), adanya kepastian yaitu pengetahuan, kesopan satunan dan kemampuan para pegawai perusahaan untuk menumbuhkan rasa percaya para pelanggan kepada pelayanan perusahaan yang memiliki beberapa komponen anatara lain:

a. Communication (komunikasi), yaitu secara terus menerus memberikan informasi kepada pelanggan dalam bahasa dan penggunaan kata yang jelas sehingga para pelanggan dapat dengan mudah mengerti disamping itu perusahaan hendaknya dapat secara cepat dan tanggap dalam menyikapi keluhan dan komplain yang dilakukan oleh pelanggan.

b. Credibility (kredibilitas), perlunya jaminan atas suatu kepercayaan yang diberikan kepada pelanggan, believability atau sifat kejujuran. Menanamkan kepercayaan, memberikan kredibilitas yang baik bagi perusahaan pada masa yang akan datang.

c. Security (keamanan), adanya suatu kepercayaan yang tinggi dari pelanggan akan pelayanan yang diterima. Tentunya pelayanan yang diberikan memberikan suatu jaminan kepercayaan yang maksimal.

d. Competence (kompetensi) yaitu ketrampilan yang dimiliki dan dibutuhkan agar dalam memberikan pelayanan kepada pelanggan dapat dilaksanakan dengan optimal.

e. Courtesy (sopan santun), dalam pelayanan adanya suatu nilai moral yang dimiliki oleh perusahaan dalam meberikan pelayanan kepada pelanggan. Jaminan akan kesopan santunan yang ditawarkan kepada pelanggan sesuai dengan kondisi dan situasi yang ada.

5. Empathy (empati), yaitu memberikan perhatian yang tulus dan bersifat individu atau pribadi yang diberikan kepada para pelanggan dengan berupaya memahami keinginan konsumen. Dimana suatu perusahaan diharapkan memiliki pengertian dan pengetahuan tentang pelanggan, memahami kebutuhan pelanggan secara spesifik, serta memiliki waktu pengoperasian yang nyaman bagi pelanggan.

\section{Pengertian Kepuasan Pelanggan}

Pada dasarnya pengertian kepuasan pelanggan mencakup perbedaan antara tingkat kepentingan dan kinerja atau hasil yang dirasakan. Ada beberapa pakar yang memberikan defenisi mengenai kepuasan/ketidakpuasan pelanggan. Menurut Kotler (1997: 40) 
kepuasan pelanggan adalah : "a person's feeling of pleasure or disappointment resulting from comparing a product's received performance (or outcome) in relations to the persons's expectation" perasaan senang atau kecewa seseorang sebagai hasil dari perbandingan antara prestasi atau produk yang dirasakan dan yang diharapkannya.

Menurut Day dalam Tjiptono (1997), menyatakan bahwa kepuasan atau ketidakpuasan pelanggan adalah respon pelanggan terhadap evaluasi ketidaksesuaian yang dirasakan antara harapan sebelumnya dan kinerja aktual produk yang dirasakan setelah pemakaiannya. Engel, et.al., (1990) menyatakan kepuasan pelanggan merupakan evaluasi purnabeli di mana alternatif yang dipilih sekurang-kurangnya sama atau melampaui harapan pelanggan, sedangkan ketidakpuasan timbul apabila hasil (outcome) tidak memenuhi harapan pelanggan. Kotler, et al., (1996) mengatakan bahwa kepuasan pelanggan adalah tingkat perasaan seseorang setelah membandingkan kinerja yang dirasakan dibandingkan dengan harapannya.

Menurut Kotler yang dikutip Tjiptono (1996:146) bahwa kepuasan pelanggan adalah tingkat perasaan seseorang setelah membandingkan kinerja (atau hasil) yang dirasakan dengan harapannya. Tingkat kepuasan adalah fungsi dari perbedaan antara kinerja yang dirasakan dengan harapan. Kualitas termasuk semua elemen yang diperlukan untuk memuaskan tujuan pelanggan, baik internal maupun ekternal, juga termasuk tiap-tiap item dalam produk kualitas, kualitas layanan, performance, availibility, durability, aesthetic, reability, maintainability, logistic, supprtability, costomer service, training, delivery, billing,shipping, repairing, marketing, warranty, dan life cycle cost. Pemahaman terhadap harapan-harapan pelanggan oleh supplier merupakan input untuk melakukan perbaikan dan peningkatan kualitas produk, baik barang maupun jasa.

Apabila harapan pelanggan terpenuhi, maka akan menjadikannya pelanggan loyal, puas terhadap produk barang atau jasa yang dibelinya. Sebaliknya, bilamana tidak puas, supplier akan ditinggalkan oleh pelanggan. Kunci keputusan pelanggan berkaitan dengan kepuasan terhadap penilaian produk barang dan jasa. Kerangka kepuasan pelanggan tersebut terletak pada kemampuan supplier dalam memahami kebutuhan, keinginan dan harapan pelanggan sehingga penyampaian produk, baik barang maupun jasa oleh supplier sesuai dengan harapan pelanggan. Selain faktor-faktor tersebut di atas, dimensi waktu juga mempengaruhi tanggapan persepsi pelanggan terhadap kualitas produk, baik barang maupun jasa. Dari defenisi di atas dapat disimpulkan kepuasan pelanggan mencakup perbedaan antara harapan dan kinerja atau hasil yang dirasakan. Konsep kepuasan pelanggan dapat dilihat pada gambar di bawah ini. 


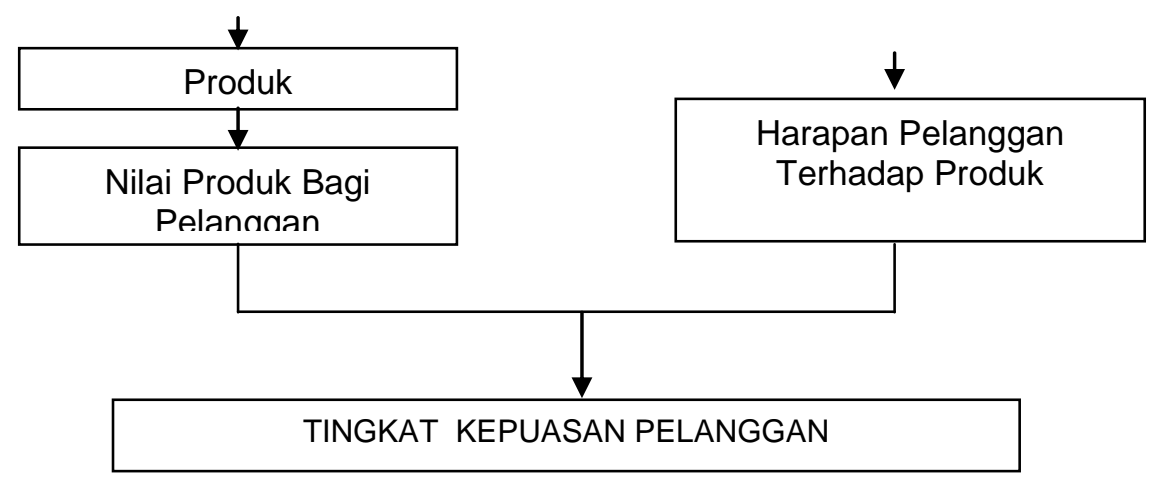

Gambar 2.1. Konsep Kepuasan Pelanggan

Sumber: Rangkuti, 2003. Konsep Kepuasan Pelanggan.

Berdasarkan Gambar 1 di atas, menunjukkan bahwa perusahaan menawarkan jasa untuk memenuhi kebutuhan dan keinginan pelanggan. Produk yang ditawarkan diharapkan sesuai dengan keinginan pelanggan sehingga akan menciptakan tingkat kepuasan pelanggan.

\section{Metode dan Teknik Pengukuran Kepuasan Pelanggan}

Pengukuran tingkat kepuasan pelanggan telah menjadi hal yang sangat esensial bagi setiap perusahaan. Hal ini menjadi umpan balik dan masukan bagi keperluan pengembangan dan implementasi strategi peningkatan kepuasan pelanggan. Pada prinsipnya kepuasan pelanggan itu dapat diukur dengan berbagai metode. Menurut Kotler,et al., (1996) mengidentifikasi empat (4) metode untuk mengukur kepuasan pelanggan yaitu :

1. Sistem Keluhan dan Saran. Setiap organisasi yang berorientasi pada pelanggan (Customer-oriented) perlu memberikan kesempatan yang luas kepada para pelanggannya untuk menyampaikan saran, pendapat dan keluhan mereka. Media yang digunakan bisa berupa kotak saran yang diletakkan di tempat-tempat strategis ( yang mudah di jangkau atau sering dilewati pelanggan), kartu komentar ( yang bisa diisi langsung maupun yang bisa dikirim via pos kepada perusahaan ), saluran telepon khusus bebas pulsa dan lain-lain. Informasi-informasi yang diperoleh melalui metode ini dapat memberikan ide-ide baru dan masukan yang berharga kepada perusahaan, sehingga memungkinkannya untuk bereaksi dengan tanggap dan cepat untuk mengatasi masalah-masalah yang timbul.

2. Ghost Shopping. Salah satu cara untuk memperoleh gambaran mengenai kepuasan pelanggan adalah dengan mempekerjakan beberapa orang (Ghost shopper) untuk berperan atau bersikap sebagai pelanggan atau pembeli potensial produk perusahaan dan pesaing. Kemudian mereka melaporkan temuan-temuannya mengenai kekuatan dan kelemahan produk perusahaan dan pesaing berdasarkan pengalaman mereka dalam pembelian produk-produk tersebut. Selain itu para ghost shopper juga dapat mengamati cara perusahaan dan pesaingnya melayani permintaan pelanggan, menjawab pertanyaan pelanggan dan menangani setiap keluhan.

3. Lost Customer Analysis. Perusahaan seyogianya menghubungi para pelanggan yang telah berhenti membeli atau yang telah pindah pemasok agar dapat memahami mengapa hal itu terjadi dan supaya dapat mengambil kebijakan perbaikan atau penyempurnaan selanjutnya. Bukan hanya exit interview saja yang perlu, tetapi pemantauan customer loss rate juga penting, di mana peningkatan customer loss rate menunjukkan kegagalan perusahaan dalam memuaskan pelanggannya. 
4. Survei kepuasan pelanggan. Banyak penelitian mengenai kepuasan pelanggan yang dilakukan dengan penelitian survey, baik dengan survey melalui pos, telepon, maupun wawancara pribadi. Melalui survey perusahaan akan memperoleh tanggapan dan umpan balik secara langsung dari pelanggan dan juga memberikan tanda positif bahwa perusahaan menaruh perhatian terhadap para pelanggannya.

Menurut Tjiptono, (1997), teknik pengukuran kepuasan pelanggan dilakukan dengan :

1. Pengukuran dapat dilakukan secara langsung dengan berbagai pertanyaan. Misalnya: Seberapa puas anda terhadap pelayanan perusahaan kami. Jawabannya dapat dibuat dengan skala : Sangat tidak puas, tidak puas, netral, puas, sangat puas.

2. Responden diberi pertanyaan mengenai seberapa besar mereka mengharapkan suatu atribut tertentu dan seberapa besar yang mereka rasakan (derived dissatisfaction)..

3. Responden diminta untuk menuliskan masalah-masalah yang mereka hadapi berkaitan dengan penawaran dari perusahaan dan juga diminta untuk menuliskan perbaikan-perbaikan yang mereka sarankan (problem analysis).

4. Responden dapat diminta merengking berbagai elemen (atribut) dari penawaran berdasarkan derajat pentingya setiap elemen dan seberapa baik kinerja perusahaan dalam masing-masing elemen.

\section{Faktor-Faktor yang Mempengaruhi Kepuasan Pelanggan}

Fokus kualitas pelayanan terletak pada kepuasan pelanggan, maka perlu dipahami komponen-komponen yang berkaitan dengan kepuasan pelanggan tersebut. Menurut Lopiyoadi (2001:150), ada lima faktor utama yang perlu dipertahankan perusahaan dalam upaya memuaskan pelanggannya adalah:

1. Kualitas produk. Pelanggan akan merasa puas bila hasil evaluasi mereka menunjukkan bahwa produk yang mereka gunakan berkualitas. Pelanggan rasional selalu menuntut produk yang berkualitas untuk setiap pengorbanan yang dilakukan untuk memperoleh produk tersebut. Dalam hal ini, kualitas produk yang baik akan memberikan nilai tambah di benak pelanggan.

2. Kualitas pelayanan. Kualitas pelayanan terutama dibidang jasa, pelanggan akan merasa puas bila mereka mendapatkan pelayanan yang baik atau yang sesuai dengan yang diharapkan. Pelanggan yang puas akan menunjukkan kemungkinan untuk kembali membeli produk yang sama. Pelanggan yang puas cenderung akan memberikan persepsi positif terhadap produk perusahaan.

3. Emosional. Pelanggan akan merasa bangga dan mendapatkan keyakinan bahwa orang lain akan kagum terhadap dia bila menggunakan produk dengan merek tertentu yang cenderung mempunyai tingkat kepuasan yang lebih tinggi. Kepuasan yang diperoleh bukan karena kualitas dari produk tetapi nilai sosial atau self esteem yang membuat pelanggan menjadi puas terhadap merk tertentu.

4. Harga. Produk yang mempunyai kualitas yang sama tetapi menetapkan harga yang relatif murah akan memberikan nilai yang lebih tinggi kepada pelanggannya.

5. Biaya. Pelanggan tidak perlu mengeluarkan biaya tambahan atau tidak perlu membuang waktu untuk mendapatkan suatu produk atau jasa cenderung puas terhadap produk atau jasa itu.

Kualitas pelayanan dapat diukur dengan menggunakan lima dimensi kualitas pelayanan yaitu tangibles, reliability, responsiveness, and assurance, empathy. Kepuasan pelanggan selain dipengaruhi oleh persepsi kualitas pelayanan, juga ditentukan oleh kualitas produk, harga dan faktor-faktor yang bersifat pribadi serta yang bersifat sesaat. Persepsi pelanggan mengenai kualitas pelayanan tidak mengharuskan pelanggan menggunakan jasa tersebut terlebih dahulu untuk memberikan penilaian. 


\section{Populasi dan Sampel}

\section{METODE PENELITIAN}

Populasi merupakan keseluruhan objek yang akan diamati . Populasi dalam penelitian ini, seluruh pelanggan PT. PLN (Persero) Perumnas Mandala Cabang Lubuk Pakam . Sampel merupakan sebagian dari anggota populasi yang dianggap dapat mewakili. Jumlah sampel dalam penelitian ini berpedoman pada pendapat Hair yang menggunakan teknik analisis faktor maka jumlah sampelnya $5 \times \mathrm{n}^{\prime \prime}(\mathrm{n}=$ jumlah variabel yang diteliti). Dalam Penelitian ini menggunakan 25 variabel (n), maka yang menjadi sampel dalam penelitian ini adalah $5 \times 25=125$ responden.

\section{Operasionalisasi Variabel}

Operasionalisasi variabel mengacu pada ke-5 (lima) dimensi kualitas jasa yaitu :.

Tabel 1. Nama Variabel, Indikator dan Skala Pengukuran

\begin{tabular}{|c|c|c|c|}
\hline No & Nama Variabel & Indikator & Skala Pengukuran \\
\hline 1. & Berwujud (Tangible) & $\begin{array}{ll}\text { 1. } & \text { Tempat Pelayanan yang aman } \\
\text { 2. Peralatan yang digunakan } \\
\text { 3. Prosedur permohonan } \\
\text { 4. Penampilan pegawai } \\
\text { 5. Kemutakhiran peralatan }\end{array}$ & Ordinal \\
\hline 2. & $\begin{array}{l}\text { Keandalan } \\
\text { (Reliability) }\end{array}$ & $\begin{array}{ll}\text { 1. } & \text { Kepedulian Petugas } \\
\text { 2. Ketepatan Waktu pelayanan } \\
\text { 3. Kecepatan pelayanan } \\
\text { 4. Kesesuaian pelaksanaan } \\
\text { 5. Sikap yang simpatik } \\
\end{array}$ & Ordinal \\
\hline 3. & $\begin{array}{l}\text { Ketanggapan } \\
\text { (Responsivenes) }\end{array}$ & $\begin{array}{ll}\text { 1. } & \text { Tanggap atas keluhan } \\
\text { 2. } & \text { Cepat menangani masalah } \\
\text { 3. Informasi yang jelas } \\
\text { 4. Pelayanan yang cepat } \\
\text { 5. } \text { Kesediaan pegawai membantu }\end{array}$ & Ordinal \\
\hline 4. & $\begin{array}{l}\text { Jaminan } \\
\text { (Assurance) }\end{array}$ & $\begin{array}{ll}\text { 1. } & \text { Keramahan Pegawai } \\
\text { 2. } & \text { Kompetensi Pegawai } \\
\text { 3. } & \text { Kredibilitas Pegawai } \\
\text { 4. } & \text { Kesabaran pegawai } \\
\text { 5. } & \text { Rasa aman selama berurusan }\end{array}$ & Ordinal \\
\hline 5. & Empati (Emphaty) & $\begin{array}{ll}\text { 1. } & \text { Sikap Karyawan } \\
\text { 2. } & \text { Perhatian petugas } \\
\text { 3. } & \text { Perlakuan yang adil } \\
\text { 4. } & \text { Perhatian yang tulus } \\
\text { 5. } & \text { Memahami kebutuan pelanggan }\end{array}$ & Ordinal \\
\hline
\end{tabular}

\section{Teknik Pengumpulan Data}

Teknik pengumpulan data yang digunakan dalam penelitian ini adalah:

1. Kuesioner, dilakukan dengan membagikan angket kepada responden yang berguna untuk mengetahui tanggapan mereka mengenai faktor-faktor yang dominan yang mempengaruhi kepuasan pelanggan dalam kemudahan pembayaran rekening listrik pada PT. PLN (Persero) Perumnas Mandala Cabang Lubuk Pakam

2. Teknik dokumentasi, dilakukan dengan mengumpulkan data yang sudah diolah sebelumnya dari PT. PLN (Persero) Perumnas Mandala Cabang Lubuk Pakam .

\section{Teknik Analisis Data}

Teknik analisis faktor digunakan untuk mereduksi data dari sejumlah variabel menjadi lebih sedikit faktor, yang bertujuan untuk mengetahui faktor-faktor paling dominan yang mempengaruhi kepuasan pelanggan pada PT. PLN (Persero) Perumnas Mandala Cabang Lubuk Pakam. Menurut Santoso dan Tjiptono, (2001:250), secara garis besar tahapan pada analisis faktor adalah:

Model dasar analisis faktor adalah data hasil observasi dari faktor-faktor $\left(\mathrm{f}_{\mathrm{n}}\right)$. Bentuk dasar model ini adalah nilai observasi dari orang ke-k $=\mathrm{f}$ (skor orang ke-k pada faktor dasar dan satu elemen acak). Secara matematis persamaan ini menjadi (Arikunto, 2002:165): 
Keterangan :

$$
X_{i k}=\lambda_{i l} f_{i k}+\lambda_{i 2} f_{2 k}+\ldots . .+\lambda_{i m} f_{m k}+e_{i k}
$$

$\mathrm{X}_{\mathrm{ik}}=$ nilai dari variabel ke-i untuk obsevasi ke-k

$\mathrm{f}_{\mathrm{jk}}=$ nilai dari faktor ke-j untuk observasi ke-k (disebut juga factor scores)

$\lambda_{\mathrm{ij}}=$ hubungan dari variabel ke-i dengan faktor ke-j, di mana $\mathrm{m}$

faktor dan $\mathrm{p}$ variabel, $\mathrm{m}<\mathrm{p}$.

$\lambda_{\mathrm{ij}}$ yang biasa disebut factor loading, menunjukkan keterkaitan faktor dengan variabel yang diukur. Secara spesifik dapat dikatakan bahwa factor loading adalah korelasi antara faktor dengan variabel. Jika angka K-M-O Measure of Sampling Adeguarcy (MSA) lebih besar 0,50, maka kumpulan variabel tersebut dapat diproses lebih lanjut.

Angka pembatas (cut off point) agar sebuah variabel dapat secara nyata termasuk sebuah faktor yang mempengaruhi nasabah untuk meminjam adalah 0,50 . Jika sebuah faktor loadingnya $\geq 0,50$, variabel dapat dimasukkan sebagai suatu faktor. Jika sebuah hasil perhitungan faktor loadingnya $<0,50$ maka variabel tidak dapat dimasukkan dalam salah satu faktor manapun.

HASIL PENELITIAN

Dari hasil output SPSS Versi 16,0 untuk 25 pertanyaan yang dijawab oleh 125 responden hasilnya sebagai berikut :

Tabel 2. KMO and Bartlett's Test

\begin{tabular}{|c|c|c|}
\hline \multicolumn{2}{|c|}{ Kaiser-Meyer-Olkin Measure of Sampling Adequacy. } & .72 \\
\hline Bartlett's Test of Sphericity & $\begin{array}{l}\text { Approx. Chi-Square } \\
\text { Df } \\
\text { Sig. }\end{array}$ & $\begin{array}{r}1272.410 \\
300 \\
.000\end{array}$ \\
\hline
\end{tabular}

Berdasarkan tabel di atas menunjukkan bahwa nilai $K M O$ and Bartlett's Test yang dilihat dari nilai KMO Measure of Sampling Adeguacy (MSA) sebesar 0,729 yang lebih besar dari 0,50 dengan signifikansi 0,000. Hal ini berarti bahwa ke 25 (dua puluh lima) faktor layak untuk dianalisis lebih lanjut untuk mengetahui faktor -faktor yang dominan mempengaruhi kepuasan pelanggan.

\section{Anti Image Correlation}

Nilai Anti image Matrrices, khususnya pada bagian bawah (Anti Image Correleation) terlihat sejumlah angka yang membentuk diagonal yang bertanda 'a' yang menandakan besaran Measure of Sampling Adeguacy (MSA) sebuah variabel. Besarnya MSA tersebut menunjukkan kecukupan pengaruh dari factor tersebut terhadap faktor-faktor yang mempengaruhi kepuasan pelanggan. Nilai MSA yang diperoleh dari 25 faktor yaitu : 0,$843 ; 0,557 ; 0,715 ; 0,694 ; 0,611 ; 0,571 ; 0,718$; 0,$795 ; 0,554 ; 0,830 ; 0,558,0,552 ; 0,598 ; 0,784 ; 0,701 ; 0,854 ; 0,625 ; 0,546 ; 0,742 ; 0,599 ; 0,805 ; 0,783$; 0,$705 ; 0,530 ; 0,780$. Dari nilai MSA tersebut ternyata nilai korelasinya lebih besar dari 0,5 , berarti ke 25 faktor yang mempengaruhi kepuasan pelanggan dapat diproses lebih lanjut. Apabila nilai MSA lebih kecil dari 0,5 maka faktor tersebut harus dikeluarkan, kemudian dilakukan pengujian kembali. 
Tabel 3. Anti-image Matrices

\begin{tabular}{|c|c|c|c|c|c|c|}
\hline & & V1 & V2 & V3 & V4 & V5 \\
\hline $\begin{array}{l}\text { Anti-image } \\
\text { Covariance }\end{array}$ & $\begin{array}{l}\text { V1 } \\
\text { V2 } \\
\text { V3 } \\
\text { V4 } \\
\text { V5 } \\
\text { V6 } \\
\text { V7 } \\
\text { V8 } \\
\text { V9 } \\
\text { V10 } \\
\text { V11 } \\
\text { V12 } \\
\text { V13 } \\
\text { V14 } \\
\text { V15 } \\
\text { V16 } \\
\text { V17 } \\
\text { V18 } \\
\text { V19 } \\
\text { V20 } \\
\text { V21 } \\
\text { V22 } \\
\text { V23 } \\
\text { V24 } \\
\text { V25 }\end{array}$ & $\begin{array}{l}.325 \\
-.068 \\
.067 \\
-.058 \\
-.137 \\
.043 \\
-.073 \\
-.052 \\
.085 \\
.002 \\
-.020 \\
.061 \\
.114 \\
.018 \\
.055 \\
.010 \\
-.007 \\
.065 \\
.035 \\
.007 \\
-.066 \\
-.006 \\
-.011 \\
.015 \\
-.032\end{array}$ & $\begin{array}{l}-.068 \\
.543 \\
.069 \\
-.123 \\
.086 \\
-.179 \\
.046 \\
-.141 \\
-.041 \\
.035 \\
.041 \\
-.070 \\
-.038 \\
.023 \\
-.059 \\
.026 \\
.044 \\
-.060 \\
-.022 \\
-.028 \\
-.017 \\
.027 \\
-.091 \\
.148 \\
-.012\end{array}$ & $\begin{array}{l}.067 \\
.069 \\
.715 \\
-.061 \\
-.156 \\
.069 \\
.065 \\
.055 \\
-.018 \\
-.011 \\
.034 \\
.004 \\
.012 \\
.013 \\
.025 \\
.016 \\
-.115 \\
-.054 \\
-.100 \\
-.049 \\
.012 \\
.042 \\
.028 \\
.045 \\
-.013\end{array}$ & $\begin{array}{l}-.058 \\
-.123 \\
-.061 \\
.430 \\
.117 \\
.125 \\
-.040 \\
-.095 \\
.014 \\
.001 \\
-.018 \\
.041 \\
-.005 \\
.028 \\
-.004 \\
.013 \\
.019 \\
-.027 \\
.078 \\
.009 \\
-.025 \\
.002 \\
-.046 \\
-.211 \\
-.013\end{array}$ & $\begin{array}{c}.086 \\
-.156 \\
.117 \\
.573 \\
-.009 \\
.055 \\
-.009 \\
-.190 \\
-.011 \\
-.014 V \\
.011 \\
-.105 \\
.010 \\
-.117 \\
.006 \\
-.021 \\
-.069 \\
.034 \\
.050 \\
-.011 \\
.083 \\
-.112 \\
.023 \\
-.009\end{array}$ \\
\hline $\begin{array}{l}\text { Anti-image } \\
\text { Correlation }\end{array}$ & $\begin{array}{l}\text { V1 } \\
\text { V2 } \\
\text { V3 } \\
\text { V4 } \\
\text { V5 } \\
\text { V6 } \\
\text { V7 } \\
\text { V8 } \\
\text { V9 } \\
\text { V10 } \\
\text { V11 } \\
\text { V12 } \\
\text { V13 } \\
\text { V14 } \\
\text { V15 } \\
\text { V16 } \\
\text { V17 } \\
\text { V18 } \\
\text { V19 } \\
\text { V20 } \\
\text { V21 } \\
\text { V22 } \\
\text { V23 } \\
\text { V24 } \\
\text { V25 }\end{array}$ & $\begin{array}{l}.843^{\mathrm{a}} \\
-.161 \\
.139 \\
-.154 \\
-.317 \\
.089 \\
-.154 \\
-.135 \\
.199 \\
.005 \\
-.056 \\
.158 \\
.227 \\
.102 \\
.108 \\
.041 \\
-.014 \\
.131 \\
.069 \\
.013 \\
-.267 \\
-.011 \\
-.023 \\
.038 \\
-.192\end{array}$ & $\begin{array}{l}-.161 \\
.557^{\mathrm{a}} \\
.111 \\
-.255 \\
.155 \\
-.287 \\
.075 \\
-.281 \\
-.074 \\
.063 \\
.089 \\
-.142 \\
-.058 \\
.103 \\
-.089 \\
.081 \\
.070 \\
-.092 \\
-.035 \\
-.041 \\
-.055 \\
.041 \\
-.146 \\
.284 \\
-.057\end{array}$ & $\begin{array}{l}.139 \\
.111 \\
.715^{\mathrm{a}} \\
-.111 \\
-.244 \\
.096 \\
.093 \\
.095 \\
-.029 \\
-.017 \\
.065 \\
.007 \\
.016 \\
.051 \\
.034 \\
.043 \\
-.159 \\
-.073 \\
-.135 \\
-.063 \\
.032 \\
.057 \\
.039 \\
.075 \\
-.051\end{array}$ & $\begin{array}{l}-.154 \\
-.255 \\
-.111 \\
.694^{a} \\
.235 \\
.226 \\
-.073 \\
-.213 \\
.028 \\
.001 \\
-.043 \\
.094 \\
-.008 \\
.138 \\
-.007 \\
.044 \\
.035 \\
-.046 \\
.135 \\
.014 \\
-.088 \\
.004 \\
-.084 \\
-.455 \\
-.068\end{array}$ & $\begin{array}{l}-.317 \\
.155 \\
-.244 \\
.235 \\
.611^{\mathrm{a}} \\
-.014 \\
.087 \\
-.017 \\
-.334 \\
-.020 \\
-.030 \\
.022 \\
-.157 \\
.042 \\
-.171 \\
.016 \\
-.032 \\
-.104 \\
.051 \\
.073 \\
-.034 \\
.124 \\
-.176 \\
.043 \\
-.042\end{array}$ \\
\hline
\end{tabular}

a. Measures of Sampling Adequacy (MSA) 
Lanjutan Tabel 3. Anti-image Matrices

\begin{tabular}{|c|c|c|c|c|c|c|c|c|}
\hline & & V6 & V7 & V8 & V9 & V10 & V11 & V12 \\
\hline $\begin{array}{l}\text { Anti-image } \\
\text { Covariance }\end{array}$ & $\begin{array}{l}\text { V1 } \\
\text { V2 } \\
\text { V3 } \\
\text { V4 } \\
\text { V5 } \\
\text { V6 } \\
\text { V7 } \\
\text { V8 } \\
\text { V9 } \\
\text { V10 } \\
\text { V11 } \\
\text { V12 } \\
\text { V13 } \\
\text { V14 } \\
\text { V15 } \\
\text { V16 } \\
\text { V17 } \\
\text { V18 } \\
\text { V19 } \\
\text { V20 } \\
\text { V21 } \\
\text { V22 } \\
\text { V23 } \\
\text { V24 } \\
\text { V25 }\end{array}$ & $\begin{array}{c}.043 \\
-.179 \\
.069 \\
.125 \\
-.009 \\
.714 \\
.018 \\
.015 \\
.077 \\
-8.742 \mathrm{E}-5 \\
.002 \\
.073 \\
-.070 \\
-.012 \\
.001 \\
-.009 \\
.083 \\
.120 \\
.028 \\
.038 \\
.034 \\
-.103 \\
-.041 \\
-.111 \\
4.323 \mathrm{E}-6\end{array}$ & $\begin{array}{l}-.073 \\
.046 \\
.065 \\
-.040 \\
.055 \\
.018 \\
.689 \\
.040 \\
-.112 \\
-.153 \\
.029 \\
-.031 \\
-.017 \\
.028 \\
.046 \\
-.058 \\
.026 \\
-.003 \\
.083 \\
-.076 \\
.056 \\
.011 \\
-.079 \\
-.079 \\
-.014\end{array}$ & $\begin{array}{l}-.052 \\
-.141 \\
.055 \\
-.095 \\
-.009 \\
.015 \\
.040 \\
.464 \\
-.116 \\
-.037 \\
.051 \\
.007 \\
-.059 \\
.003 \\
.058 \\
.010 \\
-.126 \\
.148 \\
-.016 \\
-.087 \\
.002 \\
-.041 \\
.058 \\
.007 \\
-.022\end{array}$ & $\begin{array}{l}.085 \\
-.041 \\
-.018 \\
.014 \\
-.190 \\
.077 \\
-.112 \\
-.116 \\
.565 \\
-.082 \\
.055 \\
-.009 \\
.061 \\
.003 \\
-.067 \\
-.033 \\
.028 \\
-.004 \\
-.004 \\
-.001 \\
.024 \\
-.113 \\
.112 \\
-.175 \\
.002 \\
\end{array}$ & $\begin{array}{c}.002 \\
.035 \\
-.011 \\
.001 \\
-.011 \\
-8.742 \mathrm{E}-5 \\
-.153 \\
-.037 \\
-.082 \\
.553 \\
-.036 \\
.074 \\
-.008 \\
-.032 \\
.016 \\
-.001 \\
-.057 \\
-.022 \\
-.152 \\
.056 \\
-.037 \\
.018 \\
-.078 \\
.128 \\
.008\end{array}$ & $\begin{array}{l}-.020 \\
.041 \\
.034 \\
-.018 \\
-.014 \\
.002 \\
.029 \\
.051 \\
.055 \\
-.036 \\
.396 \\
-.264 \\
.036 \\
.000 \\
.033 \\
-.019 \\
.118 \\
.094 \\
-.023 \\
-.014 \\
.081 \\
-.023 \\
.114 \\
-.008 \\
-.036\end{array}$ & $\begin{array}{l}.061 \\
-.070 \\
.004 \\
.041 \\
.011 \\
.073 \\
-.031 \\
.007 \\
-.009 \\
.074 \\
-.264 \\
.449 \\
-.118 \\
-.004 \\
.028 \\
.030 \\
-.162 \\
.011 \\
-.002 \\
.004 \\
-.075 \\
-.010 \\
-.027 \\
.016 \\
.024 \\
\end{array}$ \\
\hline $\begin{array}{l}\text { Anti-image } \\
\text { Correlation }\end{array}$ & $\begin{array}{l}\text { V1 } \\
\text { V2 } \\
\text { V3 } \\
\text { V4 } \\
\text { V5 } \\
\text { V6 } \\
\text { V7 } \\
\text { V8 } \\
\text { V9 } \\
\text { V10 } \\
\text { V11 } \\
\text { V12 } \\
\text { V13 } \\
\text { V14 } \\
\text { V15 } \\
\text { V16 } \\
\text { V17 } \\
\text { V18 } \\
\text { V19 } \\
\text { V20 } \\
\text { V21 } \\
\text { V22 } \\
\text { V23 } \\
\text { V24 } \\
\text { V25 }\end{array}$ & $\begin{array}{c}.089 \\
-.287 \\
.096 \\
.226 \\
-.014 \\
.571^{\mathrm{a}} \\
.026 \\
.026 \\
.122 \\
.000 \\
.004 \\
.129 \\
-.094 \\
-.048 \\
.001 \\
-.024 \\
.116 \\
.162 \\
.038 \\
.049 \\
.093 \\
-.139 \\
-.057 \\
-.186 \\
1.752 \mathrm{E}-5\end{array}$ & $\begin{array}{l}-.154 \\
.075 \\
.093 \\
-.073 \\
.087 \\
.026 \\
.718^{\mathrm{a}} \\
.072 \\
-.180 \\
-.248 \\
.056 \\
-.056 \\
-.023 \\
.111 \\
.062 \\
-.156 \\
.037 \\
-.003 \\
.114 \\
-.101 \\
.155 \\
.015 \\
-.113 \\
-.135 \\
-.059\end{array}$ & $\begin{array}{l}-.135 \\
-.281 \\
.095 \\
-.213 \\
-.017 \\
.026 \\
.072 \\
.795^{\mathrm{a}} \\
-.226 \\
-.074 \\
.120 \\
.015 \\
-.099 \\
.013 \\
.094 \\
.033 \\
-.217 \\
.247 \\
-.027 \\
-.140 \\
.008 \\
-.069 \\
.100 \\
.015 \\
-.110 \\
\end{array}$ & $\begin{array}{l}.199 \\
-.074 \\
-.029 \\
.028 \\
-.334 \\
.122 \\
-.180 \\
-.226 \\
.554^{\mathrm{a}} \\
-.147 \\
.116 \\
-.018 \\
.092 \\
.013 \\
-.099 \\
-.099 \\
.044 \\
-.006 \\
-.006 \\
-.002 \\
.073 \\
-.172 \\
.176 \\
-.329 \\
.008 \\
\end{array}$ & $\begin{array}{l}.005 \\
.063 \\
-.017 \\
.001 \\
-.020 \\
.000 \\
-.248 \\
-.074 \\
-.147 \\
.830^{\mathrm{a}} \\
-.077 \\
.149 \\
-.013 \\
-.142 \\
.025 \\
-.004 \\
-.090 \\
-.033 \\
-.233 \\
.082 \\
-.114 \\
.028 \\
-.123 \\
.244 \\
.037 \\
\end{array}$ & $\begin{array}{l}-.056 \\
.089 \\
.065 \\
-.043 \\
-.030 \\
.004 \\
.056 \\
.120 \\
.116 \\
-.077 \\
.558^{\mathrm{a}} \\
-.626 \\
.065 \\
-.004 \\
.058 \\
-.068 \\
.219 \\
.170 \\
-.042 \\
-.024 \\
.297 \\
-.042 \\
.215 \\
-.019 \\
-.196 \\
\end{array}$ & $\begin{array}{l}.158 \\
-.142 \\
.007 \\
.094 \\
.022 \\
.129 \\
-.056 \\
.015 \\
-.018 \\
.149 \\
-.626 \\
.552 \\
-.200 \\
-.019 \\
.046 \\
.100 \\
-.283 \\
.018 \\
-.003 \\
.007 \\
-.259 \\
-.018 \\
-.047 \\
.035 \\
.125 \\
\end{array}$ \\
\hline
\end{tabular}

a. Measures of Sampling Adequacy (MSA) 
Lanjutan Tabel 3. Anti-image Matrices

\begin{tabular}{|c|c|c|c|c|c|c|c|c|}
\hline & & V13 & V14 & V15 & V16 & V17 & V18 & V19 \\
\hline \multirow{25}{*}{$\begin{array}{l}\text { Anti-image } \\
\text { Covariance }\end{array}$} & $\mathrm{V} 1$ & .114 & .018 & .055 & .010 & -.007 & .065 & .035 \\
\hline & $\mathrm{V} 2$ & -.038 & .023 & -.059 & .026 & .044 & -.060 & -.022 \\
\hline & V3 & .012 & .013 & .025 & .016 & -.115 & -.054 & -.100 \\
\hline & V4 & -.005 & .028 & -.004 & .013 & .019 & -.027 & .078 \\
\hline & V5 & -.105 & .010 & -.117 & .006 & -.021 & -.069 & .034 \\
\hline & V6 & -.070 & -.012 & .001 & -.009 & .083 & .120 & .028 \\
\hline & V7 & -.017 & .028 & .046 & -.058 & .026 & -.003 & .083 \\
\hline & V8 & -.059 & .003 & .058 & .010 & -.126 & .148 & -.016 \\
\hline & V9 & .061 & .003 & -.067 & -.033 & .028 & -.004 & -.004 \\
\hline & V10 & -.008 & -.032 & .016 & -.001 & -.057 & -.022 & -.152 \\
\hline & V11 & .036 & .000 & .033 & -.019 & .118 & .094 & -.023 \\
\hline & V12 & -.118 & -.004 & .028 & .030 & -.162 & .011 & -.002 \\
\hline & V13 & .781 & -.002 & .011 & -.005 & .075 & -.046 & .018 \\
\hline & V14 & -.002 & .094 & -.005 & .003 & -.013 & .017 & .020 \\
\hline & V15 & .011 & -.005 & .809 & .019 & -.021 & .019 & .028 \\
\hline & V16 & -.005 & .003 & .019 & .197 & -.011 & -.009 & .028 \\
\hline & V17 & .075 & -.013 & -.021 & -.011 & .728 & -.041 & .116 \\
\hline & V18 & -.046 & .017 & .019 & -.009 & -.041 & .773 & -.067 \\
\hline & V19 & .018 & .020 & .028 & .028 & .116 & -.067 & .765 \\
\hline & V20 & .135 & .002 & -.132 & .003 & .006 & .020 & .062 \\
\hline & V21 & -.009 & -.028 & -.034 & -.116 & .029 & -.020 & -.004 \\
\hline & V22 & .064 & .010 & -.110 & .002 & -.059 & -.107 & .022 \\
\hline & V23 & -.034 & -.030 & .062 & .001 & -.010 & .053 & .022 \\
\hline & V24 & .050 & -.030 & .024 & .047 & -.040 & -.017 & .015 \\
\hline & V25 & .000 & -.073 & .018 & -.031 & -.006 & -.027 & -.017 \\
\hline \multirow{25}{*}{$\begin{array}{l}\text { Anti-image } \\
\text { Correlation }\end{array}$} & $\mathrm{V} 1$ & .227 & .102 & .108 & .041 & -.014 & .131 & .069 \\
\hline & $\mathrm{V} 2$ & -.058 & .103 & -.089 & .081 & .070 & -.092 & -.035 \\
\hline & $\mathrm{V} 3$ & .016 & .051 & .034 & .043 & -.159 & -.073 & -.135 \\
\hline & $\mathrm{V} 4$ & -.008 & .138 & -.007 & .044 & .035 & -.046 & .135 \\
\hline & V5 & -.157 & .042 & -.171 & .016 & -.032 & -.104 & .051 \\
\hline & V6 & -.094 & -.048 & .001 & -.024 & .116 & .162 & .038 \\
\hline & V7 & -.023 & .111 & .062 & -.156 & .037 & -.003 & .114 \\
\hline & V8 & -.099 & .013 & .094 & .033 & -.217 & .247 & -.027 \\
\hline & V9 & .092 & .013 & -.099 & -.099 & .044 & -.006 & -.006 \\
\hline & V10 & -.013 & -.142 & .025 & -.004 & -.090 & -.033 & -.233 \\
\hline & V11 & .065 & -.004 & .058 & -.068 & .219 & .170 & -.042 \\
\hline & V12 & -.200 & -.019 & .046 & .100 & -.283 & .018 & -.003 \\
\hline & V13 & $.598^{a}$ & -.009 & .014 & -.014 & .099 & -.059 & .024 \\
\hline & V14 & -.009 & $.784^{a}$ & -.018 & .023 & -.049 & .064 & .073 \\
\hline & V15 & .014 & -.018 & $.701^{a}$ & .048 & -.027 & .024 & .035 \\
\hline & V16 & -.014 & .023 & .048 & $.854^{a}$ & -.029 & -.024 & .073 \\
\hline & V17 & .099 & -.049 & -.027 & -.029 & $.625^{a}$ & -.055 & .156 \\
\hline & V18 & -.059 & .064 & .024 & -.024 & -.055 & $.546^{\mathrm{a}}$ & -.087 \\
\hline & V19 & .024 & .073 & .035 & .073 & .156 & -.087 & $.742^{\mathrm{a}}$ \\
\hline & V20 & .167 & .008 & -.160 & .007 & .008 & .025 & .077 \\
\hline & V21 & -.024 & -.208 & -.089 & -.606 & .079 & -.053 & -.011 \\
\hline & V22 & .082 & .036 & -.140 & .004 & -.079 & -.139 & .029 \\
\hline & V23 & -.045 & -.116 & .081 & .002 & -.014 & .071 & .030 \\
\hline & V24 & .080 & -.137 & .039 & .150 & -.066 & -.028 & .025 \\
\hline & V25 & .001 & -.818 & .067 & -.237 & -.025 & -.105 & -.067 \\
\hline
\end{tabular}

a. Measures of Sampling Adequacy (MSA) 
Lanjutan Tabel 3. Anti-image Matrices

\begin{tabular}{|c|c|c|c|c|c|c|c|}
\hline & & V20 & V21 & V22 & V23 & V24 & V25 \\
\hline $\begin{array}{l}\text { Anti-image } \\
\text { Covariance }\end{array}$ & $\begin{array}{l}\text { V1 } \\
\text { V2 } \\
\text { V3 } \\
\text { V4 } \\
\text { V5 } \\
\text { V6 } \\
\text { V7 } \\
\text { V8 } \\
\text { V9 } \\
\text { V10 } \\
\text { V11 } \\
\text { V12 } \\
\text { V13 } \\
\text { V14 } \\
\text { V15 } \\
\text { V16 } \\
\text { V17 } \\
\text { V18 } \\
\text { V19 } \\
\text { V20 } \\
\text { V21 } \\
\text { V22 } \\
\text { V23 } \\
\text { V24 } \\
\text { V25 }\end{array}$ & $\begin{array}{l}.007 \\
-.028 \\
-.049 \\
.009 \\
.050 \\
.038 \\
-.076 \\
-.087 \\
-.001 \\
.056 \\
-.014 \\
.004 \\
.135 \\
.002 \\
-.132 \\
.003 \\
.006 \\
.020 \\
.062 \\
.837 \\
.010 \\
.120 \\
-.051 \\
.084 \\
-.013\end{array}$ & $\begin{array}{l}-.066 \\
-.017 \\
.012 \\
-.025 \\
-.011 \\
.034 \\
.056 \\
.002 \\
.024 \\
-.037 \\
.081 \\
-.075 \\
-.009 \\
-.028 \\
-.034 \\
-.116 \\
.029 \\
-.020 \\
-.004 \\
.010 \\
.187 \\
.022 \\
-.019 \\
-.026 \\
.011\end{array}$ & $\begin{array}{l}-.006 \\
.027 \\
.042 \\
.002 \\
.083 \\
-.103 \\
.011 \\
-.041 \\
-.113 \\
.018 \\
-.023 \\
-.010 \\
.064 \\
.010 \\
-.110 \\
.002 \\
-.059 \\
-.107 \\
.022 \\
.120 \\
.022 \\
.769 \\
-.063 \\
.012 \\
.008\end{array}$ & $\begin{array}{l}-.011 \\
-.091 \\
.028 \\
-.046 \\
-.112 \\
-.041 \\
-.079 \\
.058 \\
.112 \\
-.078 \\
.114 \\
-.027 \\
-.034 \\
-.030 \\
.062 \\
.001 \\
-.010 \\
.053 \\
.022 \\
-.051 \\
-.019 \\
-.063 \\
.715 \\
-.067 \\
.030\end{array}$ & $\begin{array}{l}.015 \\
.148 \\
.045 \\
-.211 \\
.023 \\
-.111 \\
-.079 \\
.007 \\
-.175 \\
.128 \\
-.008 \\
.016 \\
.050 \\
-.030 \\
.024 \\
.047 \\
-.040 \\
-.017 \\
.015 \\
.084 \\
-.026 \\
.012 \\
-.067 \\
.498 \\
.013\end{array}$ & $\begin{array}{c}-.032 \\
-.012 \\
-.013 \\
-.013 \\
-.009 \\
4.323 \mathrm{E}-6 \\
-.014 \\
-.022 \\
.002 \\
.008 \\
-.036 \\
.024 \\
.000 \\
-.073 \\
.018 \\
-.031 \\
-.006 \\
-.027 \\
-.017 \\
-.013 \\
.011 \\
.008 \\
.030 \\
.013 \\
.085\end{array}$ \\
\hline $\begin{array}{l}\text { Anti-image } \\
\text { Correlation }\end{array}$ & $\begin{array}{l}\text { V1 } \\
\text { V2 } \\
\text { V3 } \\
\text { V4 } \\
\text { V5 } \\
\text { V6 } \\
\text { V7 } \\
\text { V8 } \\
\text { V9 } \\
\text { V10 } \\
\text { V11 } \\
\text { V12 } \\
\text { V13 } \\
\text { V14 } \\
\text { V15 } \\
\text { V16 } \\
\text { V17 } \\
\text { V18 } \\
\text { V19 } \\
\text { V20 } \\
\text { V21 } \\
\text { V22 } \\
\text { V23 } \\
\text { V24 } \\
\text { V25 }\end{array}$ & $\begin{array}{l}.013 \\
-.041 \\
-.063 \\
.014 \\
.073 \\
.049 \\
-.101 \\
-.140 \\
-.002 \\
.082 \\
-.024 \\
.007 \\
.167 \\
.008 \\
-.160 \\
.007 \\
.008 \\
.025 \\
.077 \\
.599 \mathrm{a} \\
.025 \\
.150 \\
-.065 \\
.130 \\
-.048 \\
\end{array}$ & $\begin{array}{l}-.267 \\
-.055 \\
.032 \\
-.088 \\
-.034 \\
.093 \\
.155 \\
.008 \\
.073 \\
-.114 \\
.297 \\
-.259 \\
-.024 \\
-.208 \\
-.089 \\
-.606 \\
.079 \\
-.053 \\
-.011 \\
.025 \\
.805 \mathrm{a} \\
.059 \\
-.052 \\
-.085 \\
.086 \\
\end{array}$ & $\begin{array}{l}-.011 \\
.041 \\
.057 \\
.004 \\
.124 \\
-.139 \\
.015 \\
-.069 \\
-.172 \\
.028 \\
-.042 \\
-.018 \\
.082 \\
.036 \\
-.140 \\
.004 \\
-.079 \\
-.139 \\
.029 \\
.150 \\
.059 \\
.783 a \\
-.085 \\
.019 \\
.031 \\
\end{array}$ & $\begin{array}{l}-.023 \\
-.146 \\
.039 \\
-.084 \\
-.176 \\
-.057 \\
-.113 \\
.100 \\
.176 \\
-.123 \\
.215 \\
-.047 \\
-.045 \\
-.116 \\
.081 \\
.002 \\
-.014 \\
.071 \\
.030 \\
-.065 \\
-.052 \\
-.085 \\
.705^{\mathrm{a}} \\
-.113 \\
.122 \\
\end{array}$ & $\begin{array}{l}.038 \\
.284 \\
.075 \\
-.455 \\
.043 \\
-.186 \\
-.135 \\
.015 \\
-.329 \\
.244 \\
-.019 \\
.035 \\
.080 \\
-.137 \\
.039 \\
.150 \\
-.066 \\
-.028 \\
.025 \\
.130 \\
-.085 \\
.019 \\
-.113 \\
.530 \mathrm{a} \\
.062 \\
\end{array}$ & $\begin{array}{c}-.192 \\
-.057 \\
-.051 \\
-.068 \\
-.042 \\
1.752 \mathrm{E}-5 \\
-.059 \\
-.110 \\
.008 \\
.037 \\
-.196 \\
.125 \\
.001 \\
-.818 \\
.067 \\
-.237 \\
-.025 \\
-.105 \\
-.067 \\
-.048 \\
.086 \\
.031 \\
.122 \\
.062 \\
.780 \mathrm{a} \\
\end{array}$ \\
\hline
\end{tabular}

a. Measures of Sampling Adequacy (MSA)

\section{Communalities}


Communalities pada dasarnya adalah jumlah varians (persentase) dari suatu variabel mula-mula yang bisa dijelaskan oleh faktor yang ada. Semua variabel dijelaskan oleh faktor yang terbentuk dengan ketentuan semakin besar communalities maka semakin erat hubungan variabel yang bersangkutan dengan faktor yang terbentuk. Hasil communalities yang diperoleh sebagai berikut:

Tabel 4. Communalities

\begin{tabular}{|c|c|c|}
\hline $\begin{array}{c}\text { Faktor - Faktor Yang Mempengaruhi } \\
\text { Kepuasan Pelanggan }\end{array}$ & Initial & Extraction \\
\hline Tempat Pelayanan yang aman ( V1) & 1.000 & .690 \\
\hline Peralatan yang digunakan ( V2 ) & 1.000 & .781 \\
\hline Prosedur permohonan ( V3 ) & 1.000 & .546 \\
\hline Penampilan pegawai ( V4 ) & 1.000 & .732 \\
\hline Kemutakhiran peralatan ( V5 ) & 1.000 & .603 \\
\hline Kepedulian Petugas ( V6 ) & 1.000 & .631 \\
\hline Ketepatan Waktu pelayanan ( V7 ) & 1.000 & .385 \\
\hline Kecepatan pelayanan ( V8) & 1.000 & .743 \\
\hline Kesesuaian pelaksanaan ( V9 ) & 1.000 & .735 \\
\hline Sikap yang simpatik ( V10 ) & 1.000 & .592 \\
\hline Tanggap atas keluhan ( V11 ) & 1.000 & .772 \\
\hline Menangani masalah ( V12 ) & 1.000 & .769 \\
\hline Informasi yang jelas ( V13 ) & 1.000 & .601 \\
\hline Pelayanan yang cepat ( V14 ) & 1.000 & .843 \\
\hline Kesediaan pegawai membantu ( V15 ) & 1.000 & .584 \\
\hline Keramahan Pegawai ( V16 ) & 1.000 & .798 \\
\hline Kompetensi Pegawai ( V17) & 1.000 & .535 \\
\hline Kredibilitas Pegawai ( V18 ) & 1.000 & .464 \\
\hline Kesabaran pegawai ( V19) & 1.000 & .708 \\
\hline Rasa aman selama berurusan ( V20 ) & 1.000 & .591 \\
\hline Sikap Karyawan ( V21 ) & 1.000 & .783 \\
\hline Perhatian petugas ( V22 ) & 1.000 & .446 \\
\hline Perlakuan yang adil ( V23 ) & 1.000 & .529 \\
\hline Perhatian yang tulus ( V24 ) & 1.000 & .688 \\
\hline Memahami kebutuan pelanggan ( V25 ) & 1.000 & .858 \\
\hline
\end{tabular}

Extraction Method: Principal Component Analysis.

Berdasarkan tabel di atas, dapat dijelaskan arti dari communalities adalah:

1. Untuk variabel Tempat Pelayanan yang aman sebesar 0,69 artinya $69 \%$ varians dari variabel Tempat Pelayanan yang aman dapat dijelaskan oleh faktor yang terbentuk.

2. Untuk variabel Peralatan yang digunakan sebesar 0,781 artinya $78,1 \%$ varians dari variabel Peralatan yang digunakan dapat dijelaskan oleh faktor yang terbentuk.

3. Untuk variabel Prosedur permohonan sebesar 0,546 artinya 54,6 \% varians dari variabel Prosedur permohonan dapat dijelaskan oleh faktor yang terbentuk. Demikian juga sampai variabel ke -25 . 


\section{Component Matrix}

Factor loading yaitu besarnya korelasi antara masing-masing variabel dengan faktor 1 , 2, 3, 4, 5, 6 , 7 dan faktor 8.. Component matrix disajikan pada tabel berikut:

Tabel 5. Component Matrix ${ }^{a}$

\begin{tabular}{|c|c|c|c|c|c|c|c|c|}
\hline \multirow{2}{*}{$\begin{array}{c}\text { Faktor - Faktor Yang Mempengaruhi } \\
\text { Kepuasan Pelanggan }\end{array}$} & \multicolumn{8}{|c|}{ Component } \\
\hline & 1 & 2 & 3 & 4 & 5 & 6 & 7 & 8 \\
\hline Tempat Pelayanan yang aman (V1) & .804 & .078 & -.164 & .022 & .075 & -.070 & -.018 & -.010 \\
\hline Peralatan yang digunakan (V2) & .149 & .407 & -.437 & .359 & .337 & .249 & -.112 & .292 \\
\hline Prosedur permohonan ( V3 ) & -.204 & -.217 & .583 & -.069 & .236 & -.028 & -.234 & .016 \\
\hline Penampilan pegawai ( V4 ) & .361 & .650 & -.123 & -.225 & .002 & .044 & -.302 & .140 \\
\hline Kemutakhiran peralatan ( V5 ) & .321 & -.233 & .533 & .171 & .082 & .197 & .213 & -.205 \\
\hline Kepedulian Petugas ( V6 ) & -.212 & .138 & -.363 & .456 & -.267 & .078 & .378 & -.085 \\
\hline Ketepatan Waktu pelayanan & .373 & .316 & .072 & -.205 & -.291 & -.103 & .050 & .038 \\
\hline Kecepatan pelayanan ( V8) & .568 & .369 & -.162 & -.031 & .302 & .223 & .083 & .330 \\
\hline Kesesuaian pelaksanaan ( V9) & .169 & .369 & .535 & -.183 & -.051 & .172 & .393 & .253 \\
\hline Sikap yang si & .582 & -.260 & .201 & .162 & -.107 & -.026 & .093 & .313 \\
\hline eluhan ( V11) & -.225 & -.535 & -.398 & -.465 & -.054 & .123 & .193 & .079 \\
\hline Menangani masalah ( V12 ) & -.340 & -.377 & -.275 & -.400 & .105 & .512 & -.047 & -.009 \\
\hline Informasi yang jelas ( V13 ) & -.192 & -.244 & -.067 & .313 & -.124 & .599 & -.166 & -.034 \\
\hline Pelayanan yang cepat ( V14 ) & .818 & -.372 & -.076 & -.045 & -.097 & .026 & .127 & -.039 \\
\hline Kesediaan pegawai membantu (V15) & -.219 & .186 & 302 & 213 & .369 & .099 & .420 & -.206 \\
\hline Keramahan Pegawai ( V16 ) & .838 & -.285 & -.006 & .040 & -.077 & .027 & .057 & -.058 \\
\hline Kompeten & .300 & .052 & .279 & -.303 & .301 & .394 & -.127 & -.102 \\
\hline Kredibilitas I & .009 & -.091 & .534 & .144 & -.095 & .065 & -.357 & .093 \\
\hline Kesabaran pegawai ( V19) & -.255 & -.380 & .155 & .204 & -.031 & -.149 & -.045 & .639 \\
\hline Rasa aman selama berurusan (V20) & .180 & .093 & -.134 & -.092 & .626 & -.322 & .105 & -.131 \\
\hline Sikap Karyawan ( V21 ) & .851 & -.175 & -.011 & .101 & -.017 & .092 & -.055 & -.073 \\
\hline Perhatian petugas ( V22 ) & -.321 & .356 & .128 & -.007 & -.139 & .264 & .298 & .152 \\
\hline Perlakuan yang adil ( V23 ) & .332 & .295 & -.024 & .359 & -.149 & .135 & -.269 & -.299 \\
\hline Perhatian yang tulus ( V24) & .147 & .570 & .134 & -.379 & -.411 & .051 & .007 & -.090 \\
\hline Memahami kebutuan pelanggan (V25) & .840 & -.351 & -.094 & -.066 & -.052 & -.001 & .114 & .025 \\
\hline
\end{tabular}

Extraction Method: Principal Component Analysis. a. 8 components extracted. Berdasarkan tabel di atas diuraikan arti component matrix sebagai berikut:

1. Hubungan variabel Tempat Pelayanan yang aman (V1) dengan faktor 1 adalah 0,804 (sangat kuat). Maka variabel ini dapat dimasukkan sebagai faktor 1 .

2. Hubungan variabel Prosedur permohonan (V3) dengan faktor 3 adalah 0,583 (cukup kuat). Maka variabel ini dapat dimasukkan sebagai faktor 3.

3. Hubungan variabel Penampilan pegawai (V4) dengan faktor 2 adalah 0,650 (cukup kuat). Maka variabel ini dapat dimasukkan sebagai faktor 2. Demikian juga penjelasan sampai variabel ke -25 yang nilainya $\leq 0,5$.

\section{Rotated Component Matrix}

Dari 25 (dua puluh lima) variabel yang dianalisis namun hanya 15 variabel yang terbentuk tentang faktor-faktor yang mempengaruhi kepuasan pelanggan. Setelah dilakukan rotasi untuk memperjelas variabel-variabel mana yang masuk ke dalam tiaptiap faktor. Banyak sekali faktor loading yang berubah setelah mengalami rotasi menjadi lebih kecil atau lebih besar seperti pada tabel berikut: 
Tabel 6. Rotated Component Matrix ${ }^{a}$

\begin{tabular}{|c|c|c|c|c|c|c|c|c|}
\hline \multirow{2}{*}{$\begin{array}{c}\text { Faktor - Faktor Yang Mempengaruhi } \\
\text { Kepuasan Pelanggan }\end{array}$} & \multicolumn{8}{|c|}{ Component } \\
\hline & 1 & 2 & 3 & 4 & 5 & 6 & 7 & 8 \\
\hline Tempat Pelayanan yang aman ( V1) & .689 & .140 & .298 & .168 & -.031 & -.104 & -.206 & .154 \\
\hline Peralatan yang digunakan ( V2 ) & -.033 & -.141 & .829 & .150 & -.217 & -.042 & .037 & .029 \\
\hline Prosedur permohonan ( V3 ) & -.167 & -.174 & -.233 & .082 & .616 & .151 & .003 & -.155 \\
\hline Penampilan pegawai ( V4 ) & .024 & .538 & .532 & .191 & .121 & -.233 & -.111 & .202 \\
\hline Kemutakhiran peralatan ( V5 ) & .405 & -.108 & -.218 & .163 & .260 & .513 & .134 & .060 \\
\hline Kepedulian Petugas ( V6 ) & -.142 & -.104 & .019 & .097 & .725 & .134 & .212 & .027 \\
\hline Ketepatan Waktu pelayanan ( V7 ) & .227 & .550 & .021 & .135 & -.039 & -.045 & -.083 & .042 \\
\hline Kecepatan pelayanan ( V8) & .360 & .228 & .720 & .007 & .016 & .142 & -.149 & .010 \\
\hline Kesesuaian pelaksanaan ( V9 ) & .042 & .552 & .087 & .053 & .171 & .595 & -.013 & -.188 \\
\hline Sikap yang simpatik ( V10 ) & .649 & .051 & .032 & .134 & .075 & .088 & .063 & -.362 \\
\hline Tanggap atas keluhan ( V11) & .027 & -.130 & -.191 & .815 & -.128 & -.177 & .007 & -.075 \\
\hline Menangani masalah ( V12 ) & -.167 & -.201 & .034 & .758 & .130 & -.074 & .283 & .146 \\
\hline Informasi yang jelas ( V13 ) & -.048 & -.318 & .083 & -.099 & -.013 & .035 & .688 & .075 \\
\hline Pelayanan yang cepat ( V14) & .911 & .036 & -.027 & -.079 & -.018 & -.037 & -.029 & .044 \\
\hline Kesediaan pegawai membantu (V15) & -.243 & -.181 & .002 & .127 & -.023 & .663 & -.139 & .127 \\
\hline Keramahan Pegawai ( V16 ) & .887 & .038 & .015 & .061 & .029 & -.022 & -.007 & .069 \\
\hline Kompetensi Pegawai ( V17) & .202 & .113 & .213 & -.139 & .528 & .226 & .044 & .292 \\
\hline Kredibilitas Pegawai ( V18 ) & .004 & .000 & -.141 & .321 & .471 & .016 & .291 & -.187 \\
\hline Kesabaran pegawai ( V19 ) & -.086 & -.236 & -.048 & -.038 & .085 & -.064 & .113 & .785 \\
\hline Rasa aman selama berurusan ( V20 ) & .073 & -.222 & .215 & .007 & .070 & .075 & .668 & .180 \\
\hline Sikap Karyawan ( V21 ) & .842 & .026 & .142 & .152 & .080 & -.041 & .035 & .142 \\
\hline Perhatian petugas ( V22 ) & -.377 & .289 & .099 & -.058 & -.160 & .369 & .197 & .850 \\
\hline Perlakuan yang adil ( V23 ) & .188 & .055 & .163 & .499 & -.067 & -.097 & .246 & .374 \\
\hline Perhatian yang tulus ( V24 ) & -.076 & .785 & -.008 & .089 & .003 & -.006 & .040 & .237 \\
\hline Memahami kebutuan pelanggan (V25) & .915 & .045 & .032 & -.087 & .001 & -.057 & -.080 & .004 \\
\hline
\end{tabular}

Extraction Method: Principal Component Analysis.

Rotation Method: Varimax with Kaiser Normalization.

Rotation converged in 10 iterations.

Berdasarkan Tabel di atas diuraikan arti Rotated Component Matrix ${ }^{a}$ sebagai berikut:

1. Hubungan variabel Tempat Pelayanan yang aman (V1) dengan faktor 1 sebelum rotasi sebesar 0,804 (sangat kuat) setelah dilakukan rotasi nilainya diperkecil menjadi 0,689 (cukup kuat). Maka variabel ini dapat dimasukkan sebagai komponen faktor 1.

2. Hubungan variabel peralatan yang digunakan (V2) dengan faktor lainya lemah setelah dilakukan rotasi nilainya diperbesar menjadi 0,829 (sangat kuat). Maka variabel ini dapat dimasukkan sebagai komponen faktor 3.

3. Hubungan variabel Prosedur permohonan (V3) dengan faktor 3 sebelum rotasi 0, 583. Setelah dilakukan rotasi nilainya diperbesar menjadi 0,616 (cukup kuat). Maka variabel ini dapat dimasukkan sebagai komponen faktor 5.

4. Hubungan variabel Penampilan pegawai (V4) dengan faktor 2 sebelum rotasi 0,650 (cukup kuat). Setelah dilakukan rotasi nilainya diperkecil menjadi o,538. Maka variabel ini dapat dimasukkan sebagai faktor 2. Demikian juga penjelasan sampai variabel ke -25 yang nilainya $\leq 0,5$.

Dari uraian di atas ternyata dari 25 (dua puluh lima) faktor yang mempengaruhi kepuasan pelanggan hanya 23 (dua puluh tiga) faktor yang memiliki korelasi di atas 0,5 setelah dilakukan rotasi. Untuk lebih jelasnya, dapat dibuat ringkasan nilai korelasi dari 
faktor-faktor yang dominan mempengaruhi kepuasan pelanggan pada PT. PLN Persero Wilayah Sumut Cabang Lubuk Pakam Ranting Medan Denai

Tabel 7. Faktor-Faktor yang Dominan Mempengaruhi Kepuasan Pelanggan PT. PLN Persero Wilayah Sumut Cabang Lubuk Pakam Ranting Medan Denai

\begin{tabular}{|l|c|c|}
\hline \multicolumn{1}{|c|}{ Nama Variabel } & Korelasi & Faktor \\
\hline Memahami kebutuhan pelanggan (V25) & 0,915 & \\
Pelayanan yang cepat (V14) & 0,911 & \\
Keramahan pegawai (V16) & 0,887 & 1 \\
Sikap Karyawan (V21) & 0,842 & \\
Tempat pelayanan yang aman (V1) & 0,689 & \\
Sikap yang simpatik (V10) & 0,649 & 2 \\
\hline Perhatian yang tulus (V24) & 0,785 & \\
Ketepatan waktu pelayanan (V7) & 0,550 & 3 \\
Penampilan pegawai (V4) & 0,538 & \\
& & \\
\hline Peralatan yang digunakan (V2) & 0,829 & \\
Kecepatan pelayanan (V8) & 0,720 & \\
\hline Tanggap atas keluhan (V1) & 0,815 & \\
Menangani masalah (V12) & 0,758 & \\
\hline Kepedulian petugas (V6) & 0,725 & \\
Presedur permohonan (V3) & 0,616 & \\
Kompetensi pegawai (V17) & 0,528 & \\
\hline Kesediaan pegawai membantu (V15) & 0,663 & \\
Kesesuaian pelaksanaan (V9) & 0,595 & \\
Kemutakhiran peralatan (V5) & 0,513 & \\
\hline Informasi yang jelas (V13) & 0,688 & \\
Rasa aman selama berurusan (V20) & 0,668 & \\
\hline Perhatian petugas (V22) & 0,850 & \\
Kesabaran pegawai (V19) & 0,785 & \\
\hline Sumber : Diolah dari Tabel6 & & \\
\hline
\end{tabular}

Sumber : Diolah dari Tabel 6

\section{PEMBAHASAN}

Nilai KMO Measure of Sampling Adeguacy (MSA) sebesar 0,729 yang lebih besar dari 0,50 dengan signifikansi 0,000. Hal ini berarti bahwa ke 25 (dua puluh lima) faktor layak untuk dianalisis lebih lanjut untuk mengetahui faktor -faktor yang dominan mempengaruhi kepuasan pelanggan. Selain nilai KMO Measure of Sampling Adeguacy (MSA) juga terdapat nilai Anti image Matrrices (lihat tabel 4.3), khususnya pada bagian bawah (Anti Image Correleation) terlihat sejumlah angka yang membentuk diagonal yang bertanda ' $a$ ' yang menandakan besaran Measure of Sampling Adeguacy (MSA) sebuah variabel. Besarnya MSA tersebut menunjukkan kecukupan pengaruh dari factor tersebut terhadap faktor-faktor yang mempengaruhi kepuasan pelanggan. Nilai MSA yang diperoleh dari 25 faktor yaitu : 0,$843 ; 0,557 ; 0,715 ; 0,694 ; 0,611 ; 0,571 ; 0,718 ; 0,795 ; 0,554 ; 0,830 ; 0,558,0,552$; 0,598; 0,784; 0,701; 0,854; 0,625; 0,546; 0,742; 0,599; 0,805; 0,783; 0,705; 0,530; 0,780. Dari nilai MSA tersebut ternyata nilai korelasinya lebih besar dari 0,5 , berarti ke 25 faktor yang mempengaruhi kepuasan pelanggan dapat diproses lebih lanjut. Hal ini menjelaskan bahwa semua variabel yang diamati sangat mendukung untuk meneliti lebih lanjut faktor-faktor yang Mempengaruhi Kepuasan Pelanggan pada PT. PLN Persero Wilayah Sumut Cabang Lubuk Pakam Ranting Medan Denai .

Berdasarkan tabel 4.5 Component Matrix ${ }^{a}$ dan Tabel 4.6. Rotated Component Matrix ${ }^{a}$ menunjukkan dari 25 (dua puluh lima ) variabel yang diamati sebelum rotasi terdapat 15 variabel yang mempunyai koefisien korelasi di atas 0,5 . Setelah dilakukan rotasi 
bertambah jumlah variabel yang mempunyai nilai korelasi diatas 0,5 menjadi 23 variabel sebagai faktor yang dominan yang Mempengaruhi Kepuasan Pelanggan pada PT. PLN Persero Wilayah Sumut Cabang Lubuk Pakam Ranting Medan Denai. Dari 23 (dua puluh tiga) variabel sebagai faktor yang dominan dikelompokkan menjadi 8 (delapan) faktor.

Tingkat kepuasan pelanggan sangat ditentukan sejauh mana pihak perusahaan mampu memahami kebutuhan pelanggan, memberikan pelayanan yang cepat, sikap karyawan yang ramah, tempat pelayanan yang aman dan sikap yang penuh perhatian terhadap pelanggan, Perhatian yang tulus, Ketepatan waktu pelayanan, Penampilan pegawai, Peralatan yang digunakan, Kecepatan pelayanan, Tanggap atas keluhan, Menangani masalah, Kepedulian petugas, Presedur permohonan, Kompetensi pegawai, Kesediaan pegawai membantu, Kesesuaian pelaksanaan dan Kemutakhiran peralatan, Informasi yang jelas, Rasa aman selama berurusan, Perhatian petugas dan Kesabaran pegawai. Dari 23 (dua puluh tiga) atribut yang dipentingkan pelanggan untuk menciptakan kepuasan merupakan suatu keharusan yang harus dilakukan agar tetap eksis di masa yang akan datang. Untuk menciptakan tingkat kepuasan pelanggan (Pelanggan eksternal) terlebih dahulu menciptakan kepuasan pelanggan internal (para karyawan). .

\section{Component Transformation Matrix}

Tabel 8. Component Transformation Matrix.

\begin{tabular}{|c|c|c|c|c|c|c|c|c|}
\hline $\begin{array}{c}\text { Compo } \\
\text { nent }\end{array}$ & 1 & 2 & 3 & 4 & 5 & 6 & 7 & 8 \\
\hline 1 & .904 & .223 & .239 & .194 & .079 & -.024 & -.125 & .127 \\
2 & -.396 & .577 & .467 & .410 & -.139 & .127 & -.149 & .258 \\
3 & -.024 & .184 & .667 & .354 & .429 & .333 & .090 & -.205 \\
4 & .050 & -.517 & .131 & .665 & -.362 & .151 & .302 & -.158 \\
5 & -.085 & -.528 & .458 & -.094 & .629 & .276 & -.521 & .127 \\
6 & .036 & -.006 & .375 & -.349 & .135 & .714 & .455 & .275 \\
7 & .123 & .106 & -.152 & -.274 & -.542 & .456 & .730 & -.118 \\
8 & -.006 & .163 & .446 & -.142 & .057 & -.065 & .048 & .863 \\
\hline
\end{tabular}

Extraction Method: Principal Component Analysis.

Rotation Method: Varimax with Kaiser Normalization

Bersarkan tabel di atas dapat dijelaskan bahwa pada factor 1 dengan komponen 1 berada di atas $0,5(0,904)$, factor 2 dengan komponen 2 berada di atas $0,5(0,577$, factor 3 dengan komponen 3 berada di atas $0,5()(0,667)$, factor 4 dengan komponen 4 berada diatas $0,5(0,665)$, factor 5 dengan komponen 5 berada di atas 0,5 (0,629), factor 6 dengan komponen 6 berada di atas $0,5(0,714)$, factor 7 dengan komponen 7 berada di atas 0,5 $(0,730)$ dan factor 8 dengan komponen 8 berada di atas $0,5(0,863)$. Dari analisis tersebut maka terbentuknya factor $1,2,3,4,5,6,7,8$ sudah tepat karena terdapat interkorelasi antar faktor. Hal ini membuktikan bahwa 8 (delapan) faktor (component) yang terbentuk sudah tepat karena mempunyai korelasi tinggi. Artinya setiap faktor yang mempengaruhi kepuasan pelanggan akan saling berhubungan satu sama lain.

\section{Faktor - Faktor yang Dominan Mempengaruhi Kepuasan Pelanggan.}

Dari 25 (dua puluh lima ) variabel yang diamati kemudian di analisis dengan analisis faktor sebelum rotasi terdapat 15 variabel yang mempunyai koefisien korelasi di atas 0,5 . Kemudian setelah dilakukan rotasi bertambah jumlah variabel yang mempunyai nilai korelasi diatas 0,5 menjadi 23 variabel sebagai faktor yang dominan mempengaruhi kepuasan pelanggan. Dari 23 (dua puluh tiga) variabel sebagai faktor yang dominan dikelompokkan menjadi 8 (delapan) faktor. FAKTOR 1 : Memahami kebutuhan 
pelanggan, Pelayanan yang cepat, Keramahan pegawai, Sikap Karyawan, Tempat pelayanan yang aman dan Sikap yang simpatik. FAKTOR 2 : Perhatian yang tulus, Ketepatan waktu pelayanan dan Penampilan pegawai. FAKTOR 3 : Peralatan yang digunakan dan Kecepatan pelayanan, FAKTOR 4 : Tanggap atas keluhan dan Menangani masalah, FAKTOR 5 : Kepedulian petugas, Presedur permohonan dan Kompetensi pegawai, FAKTOR 6 : Kesediaan pegawai membantu, Kesesuaian pelaksanaan dan Kemutakhiran peralatan, FAKTOR 7 : Informasi yang jelas dan Rasa aman selama berurusan dan FAKTOR 8 : Perhatian petugas dan Kesabaran pegawai.

\section{KESIMPULAN}

1. Nilai KMO Measure of Sampling Adeguacy (MSA) sebesar 0,729 yang lebih besar dari 0,50 dengan signifikansi 0,000. Hal ini berarti bahwa ke 25 (dua puluh lima) faktor layak untuk dianalisis lebih lanjut untuk mengetahui faktor -faktor yang dominan mempengaruhi kepuasan pelanggan. Selain nilai KMO Measure of Sampling Adeguacy (MSA) juga terdapat nilai Anti image Matrrices ( lihat tabel 4.3), khususnya pada bagian bawah (Anti Image Correleation ) terlihat sejumlah angka yang membentuk diagonal yang bertanda ' $a$ ' yang menandakan besaran Measure of Sampling Adeguacy (MSA) sebuah variabel. Besarnya MSA tersebut menunjukkan kecukupan tentang faktor-faktor yang mempengaruhi kepuasan pelanggan.

2. Nilai Component Matrixa dan Nilai Rotated Component Matrixa menunjukkan dari 25 (dua puluh lima ) variabel yang diamati sebelum rotasi terdapat 15 variabel yang mempunyai koefisien korelasi di atas 0,5. Setelah dilakukan rotasi bertambah jumlah variabel yang mempunyai nilai korelasi diatas 0,5 menjadi 23 variabel sebagai faktor yang dominan yang Mempengaruhi Kepuasan Pelanggan pada PT. PLN Persero Wilayah Sumut Cabang Lubuk Pakam Ranting Medan Denai.

3. Dari 23 (dua puluh tiga) variabel sebagai faktor dominan yang mempengaruhi kepuasan pelanggan dari masing-masing faktor yaitu : FAKTOR 1: Memahami kebutuhan pelanggan , Pelayanan yang cepat, Keramahan pegawai, Sikap Karyawan, Tempat pelayanan yang aman dan Sikap yang simpatik. FAKTOR 2: Perhatian yang tulus, Ketepatan waktu pelayanan dan Penampilan pegawai. FAKTOR 3 : Peralatan yang digunakan dan Kecepatan pelayanan, FAKTOR 4 : Tanggap atas keluhan dan Menangani masalah, FAKTOR 5 : Kepedulian petugas, Presedur permohonan dan Kompetensi pegawai, FAKTOR 6 : Kesediaan pegawai membantu, Kesesuaian pelaksanaan dan Kemutakhiran peralatan, FAKTOR 7 : Informasi yang jelas dan Rasa aman selama berurusan dan FAKTOR 8 : Perhatian petugas dan Kesabaran pegawai.

\section{SARAN}

Sebaiknya pihak PT. PLN (Persero) Wilayah Sumut Cabang Lubuk Pakam Ranting Medan Denai perlu melakukan beberapa hal untuk menciptakan kepuasan pelanggan yang optimal yaitu : meningkatkan kualitas pelayanan yang cepat dan tepat melalui pelatihan dan pengembangan pegawai, mensosialisasikan sistem peralatan yang manual dengan komputerisasi dalam memberikan berbagai kemudahan bagi pelanggan dan menjalin hubungan yang saling menguntungkan

\section{DAFTAR PUSTAKA}

Assauri, Sofjan .2003. “Customer Service yang Baik Landasan Pencapaian Customer Satisfaction" dalam Usahawan, No. 01, Tahun XXXII, Januari, hal.25-30. Jakarta

Arikunto, Suharsimi, 1996, Prosedur Penelitian, Rineka Cipta, Jakarta.

Engel, J.F., et al. (1990), Consumer Behavior, $6^{\text {th }}$ ed, Chicago : The Dryden Press

Fandy Tjiptono,1996, Manajemen Jasa, Andi Offset, Yogyakarta. 
1997, Strategi Pemasaran, Andi Offset, Yogyakarta.

2001, Strategi Bisnis dan Manajemen, Andi Offset, Yogyakarta.

Kotler, Philip .2003. Marketing Management. New Jersey: Prentice Hall. 2000, Marketing Management: Analysis Planning Implemebtation and Control, Millenium Edition, Englewood Cliffs, New Jersey : Prentice Hall, Inc.

1997, Dasar-dasar Pemasaran, Alih Bahasa Alexander Sindoro, Prenhalindo, Jakarta.

Lupiyoadi, Rambat, 2001, Manajemen Pemasaran Jasa : Teori dan Praktik, Penerbit Salemba Empat, Edisi Pertama, Jakarta.

Muhaemin .2005. Analisis Faktor-faktor yang Mempengaruhi Kepuasan Nasabah PT. Bank BPD Jateng Cabang Surakarta (Tesis). Surakarta: Universitas Muhammadiyah Surakarta.

Rangkuti, Freddy .2003. Riset Pemasaran. Jakarta: Gramedia Pustaka Ulama

Rustika Atmawati dan M. Wahyuddin, 2004, “Analisis Pengaruh Kualitas Pelaynanan Terhadap Kepuasan Konsumen Pada Matahari Departement Store di Solo Grand Mall", Tesis, program Pascasarjana UMS, Surakarta.

Santono, Singgih dan Tjiptono, Fandy, 2001. Riset Pemasaran: Konsep dan Aplikasi dengan SPSS, Edisi Pertama, Jakarta: Alex Media Komputindo

Sugiyono, 1994, Statistik Untuk Penelitian, Alfabeta, Bandung.

Susanto, Herry .2001. Analisis Faktor-faktor yang Mempengaruhi Kepuasan Nasabah BPR BKK Karangmalang Kabupaten Sragen (Tesis). Surakarta: Universitas Muhammadiyah Surakarta.

Tjiptono, Fandi dan Gregorius Candra .2005. Service, Quality, and Satisfaction. Yogyakarta: Andi Offset.

Wahyuddin, M. dan Ambar Muryati .2001. “Faktor-faktor yang Mempengaruhi Kepuasan Pelanggan Perusahaan Daerah Air Minum (PDAM) Kabupaten Klaten" dalam Jurnal Manajemen Daya Saing, Vol. 2, No. 2, Desember, hal. 188-197. Program Pascasarjana UMS.

Zeithmal, Valerie A, Leonard L., Berry and Parasuraman A, 1990, "The Behavioral Consequences of Service Quality, Journal of Marketing, Vol. 60, pp. 31-46. 